\title{
Occurrence, biology and behavior of Liogenys fuscus Blanchard (Insecta, Coleoptera, Scarabaeidae) in Aquidauana, Mato Grosso do Sul, Brazil
}

\author{
Sérgio Roberto Rodrigues ${ }^{1}$, Crislany de Lima Barbosa ${ }^{1}$, Anderson Puker ${ }^{1}$, Alfredo Raul Abot ${ }^{1} \&$ Sergio Ide $^{2}$
}

${ }^{1}$ Universidade Estadual de Mato Grosso do Sul, Rodovia Aquidauana / CERA km 12, 79200-000 Aquidauana-MS, Brazil. sergio@uems.br, cris_entoagro@hotmail.com, puker86@hotmail.com, arabot@uems.br

${ }^{2}$ Centro de Pesquisa e Desenvolvimento de Sanidade Vegetal, Instituto Biológico, Av. Conselheiro Rodrigues Alves 1252, 04014-900 São Paulo-SP, Brazil. ide@ biologico.sp.gov.br

\begin{abstract}
Occurrence, biology and behavior of Liogenys fuscus Blanchard (Insecta, Coleoptera, Scarabaeidae) in Aquidauana, Mato Grosso do Sul, Brazil. Due to the importance of some Pleurosticti Scarabaeidae as agricultural pests allied to information absence on the species that occur in Brazilian Central-West region, on studies occurrence, biology and behavior on this group of scarabs were conducted. Biology and behavioral studies started with Liogenys fuscus Blanchard, 1850 (Melolonthinae), a very common species and were developed in Aquidauana, Mato Grosso do Sul. Adult beetles were collected from light traps from February 2005 to January 2007, at the experimental farm of the Universidade Estadual de Mato Grosso do Sul in Aquidauana (UEMS). In the laboratory adults were placed in plastic containers with soil with sprouts of Brachiaria decumbens Stapf (Poaceae). Eggs were transferred to a climatized chamber at $26 \pm 1^{\circ} \mathrm{C}$ with a 12-hour-light, 12-hour darkness photoperiod cycle. Adult flight activity occurred in August and in September to December from 06:00 pm to 06:00 am, with the largest number of individuals flying from 07:00 to 10:00 pm. Eggs measured $1 \times 1.5 \mathrm{~mm}$ and were laid individually or in groups in soil chambers; eggs were initially white and became yellow near hatching. The embryonic period lasted 14.3 days; first, second and third instars lasted 28.5, 48.8, and 68.2 days, respectively. The pre-pupal period lasted 120.2 days and the pre-pupa stayed inactive in soil. The mean duration of pupal stage was 27.5 days and the mean longevity of adults was 23.6 days. In laboratory the calling behavior between males and females was observed; copulation lasted, in mean, 25 minutes.
\end{abstract}

KEYWORDS. white grubs; soil pests; Scarabaeoidea; Insecta

RESUMO. Ocorrência, biologia e comportamento de Liogenys fuscus Blanchard (Insecta, Coleoptera, Scarabaeidae) em Aquidauana, Mato Grosso do Sul, Brasil. Devido à importância de alguns Scarabaeidae Pleurosticti como causadores de danos à agricultura, aliada à ausência de informações sobre as espécies que ocorrem na região Centro Oeste, foram desenvolvidos estudos sobre a ocorrência, biologia e comportamento sobre este grupo de escarabeídeos. Foram iniciados com Liogenys fuscus Blanchard, 1850 (Melolonthinae), espécie muito comum em Aquidauana, Mato Grosso do Sul, Brasil. Na fazenda experimental da Universidade Estadual de Mato Grosso do Sul (UEMS), campus de Aquidauana, foi instalada diariamente, armadilha luminosa, de fevereiro de 2005 a janeiro de 2007 para coleta dos adultos. Os adultos coletados foram encaminhados para laboratório e acondicionados em caixas de plástico, contendo solo e mudas de Brachiaria decumbens Stapf (Poaceae). Foi possível obter ovos e realizar os estudos de biologia, em câmara climatizada a $26 \pm 1^{\circ} \mathrm{C}$ e fotofase de 12 horas. Os adultos revoaram entre agosto e setembro a dezembro nos dois anos de estudos, nos horários das $18 \mathrm{~h} 00$ às $6 \mathrm{~h} 00$, em maior quantidade das $19 \mathrm{~h} 00$ às $22 \mathrm{~h} 00$. Os ovos, de 1,5 x 1,0 mm, foram depositados no solo individualmente ou agrupados em câmaras; possuem coloração branca e quando estão próximos da eclosão adquirem cor amarela. O período embrionário durou 14,3 dias, o primeiro, segundo e terceiro instares duraram 28,5, 48,8 e 68,2 dias respectivamente. O período de pré-pupa, que permaneceu inativa no solo, durou 120,2 dias. A fase de pupa durou em média de 27,5 dias e os adultos apresentaram longevidade média de 23,6 dias. Em laboratório foi observado comportamento de chamamento entre machos e fêmeas e a cópula durou em média 25 minutos.

PALAVRAS-CHAVE. Corós; pragas de solo; Scarabaeoidea; Insecta.

Among the Pleurosticti Scarabaeidae (Coleoptera), many species are crop pests with larvae and adults damaging plants (Ochieng et al. 2002). In Brazil during the 1980s larvae of species of this group of scarabs, mainly Diloboderus abderus Sturm, 1826 (Dynastinae), attained the economic damage level, causing losses in winter and spring crops in regions of state of Rio Grande do Sul (Silva \& Loeck 1996). In the central-west region of state of Paraná since 1985 / 1986, larvae of
Scarabaeidae, especially Phyllophaga cuyabana (Moser, 1918) (Melolonthinae) (Oliveira et al. 1996) were found damaging soybean (Glycine max (L.) Merr. - Fabaceae).

In these regions, the increase of soil Pleurosticti scarab populations has led to research on their biology (Oliveira et al. 1996; Silva \& Loeck 1996). In order to establish control measures, the economic damage level was studied and defined (Silva \& Costa 2002). Researches on the influence of soil 
management techniques on behavior and density of larvae were carried out (Oliveira et al. 2000). Tests to evaluate the efficiency in the use of chemical products in control of larvae were also done (Silva \& Boss 2002).

In the Brazilian Central-West region, that includes states of Mato Grosso, Mato Grosso do Sul and Goiás, Ávila \& Pípolo (1992) verified damages by Pleurosticti larvae in about 1,000 hectares of wheat (Triticum spp. - Poaceae) in the Mato Grosso do Sul (MS) municipalities of Douradina, Dourados, Fátima do Sul, Rio Brilhante and Itaporã. The larvae feed on roots causing wilting, yellowing and death of plants. The economic losses resulted of reduction of plant density in the area.

In spite of economic importance that this group of beetles can attain, little information is available especially for the Central-West Brazil. For this reason surveys were started with the aim of better known the occurring species as well as studies on their biology and behavior. In Aquidauana large number of adults of Liogenys fuscus Blanchard, 1850 (Melolonthinae) were found in crops and pasture areas. The species is poorly known and this paper presents data on its occurrence, biology and behavior.

\section{MATERIALAND METHODS}

Adults collecting and reproduction period study. This study was conducted on the campus of the Unidade Universitária de Aquidauana, Universidade Estadual de Mato Grosso do Sul (UEMS). Adults of L. fuscus were collected with light traps settled daily from February 2005 to January 2007; many Pleurosticti Scarabaeidae species are attracted to lights (Novelo \& Morón 2005; Pardo-Locarno et al. 2005). The trap was operated between crops and pasture areas from 06:00 pm to 06:00 am.

Some females were set apart and dissected to determine the stage of reproductive period according methodology employed by Crocker et al. (1999) in the study of reproduction of Phyllophaga spp.

Biology. For studies of biology, adults of L. fuscus were kept in plastic containers ( $30 \times 19 \times 12 \mathrm{~cm}$ ) with soil and sprouts of Brachiaria decumbens Stapf cv. Basilisk (Poaceae) and covered by thin fabric. The containers were checked daily, when the soil was sieved and the eggs separated. The eggs were maintained in climatized chamber $\left(26 \pm 1^{\circ} \mathrm{C}\right.$ and 24 hours scotophase) in Petri dishes with humidified soil. After hatching the larvae were reared individually in plastic pots $(500 \mathrm{ml})$ with soil and shoots of $B$. decumbens (which were replaced weekly) in climatized chamber $\left(26 \pm 1^{\circ} \mathrm{C}\right.$ and 12 hours photophase) until the adult stage. The adults were transferred individually or in pairs, to plastic boxes with soil and $B$. decumbens to verify the longevity and to observe oviposition.

Evaluation of embryonic, larval and pupal periods and longevity of adults was made using the methods of Oliveira $e t$ al. (1996), who studied the biology of P. cuyabana. In intervals of three to four days measurement of cephalic head largest width was performed in 50 larvae as in Oliveira et al. (1996).
Flight activity and sexual behavior. Flight activity was observed at the light trap on October, 11, 19, 25 and November, 2 and 9,2006. The trap was checked every 30 minutes from 06:00 pm to 06:00 am. The adults were taken to the laboratory for observation of sexual behavior. The data were transformed in $\sqrt{x+1}$ and analyzed through Tukey test $(5 \%$ of probability).

\section{RESULTS AND DISCUSSION}

Adult occurrence and reproductive period. The population dynamics of adults of $L$. fuscus is well defined by flight activity starting in August and September and ending in December (Fig. 1). During the first year 897 adults were collected. The first specimens appeared in September when 236 specimens (26.31\%) were captured. In October a total of 441 adults $(49.16 \%)$ was collected. In November and December adults were still found in the field but in low numbers (Fig. 1). No adults occurred from January to August.

In 2006, adults did not occur from January to July. The first specimens were captured at end of August, a month earlier than in 2005. A total of 2,941 adults was collected, being three in August, 1,954 (64.44\%) in September and 731 (24.86\%) in October (Fig. 1). September was the month with highest occurrence of L. fuscus. As in 2005 the largest quantity of adults occurred at the beginning of flight season and diminished from November and December.

Oliveira \& Garcia (2003) verified that the flight season of $P$. cuyabana occurs between November and December and lasts an average of 48.30 days.

During 2005 none of the dissected females were found with eggs in September. Female with developing egg was firstly collected on October 10, about 15 days after the flight season began. The mean number of eggs per female in October was 12 (range: $6-15 ; \mathrm{n}=48$ ). In November the mean number of eggs increased to 16 (range: $12-18 ; n=30$ ). In December the mean decreased to four per female (range: $2-6 ; n=13$ ).

In 2006, the first females with eggs appeared about 20 days after the flight period started. In September the mean number of eggs per female was 9.0 (range: $5-12 ; \mathrm{n}=29$ ); in October the mean increased to 15.60 (range: $8-17 ; n=32$ ). In November and December to mean decreased to 12.60 (range: $7-15 ; \mathrm{n}=$ 27) and 6.0 (range: $2-8 ; \mathrm{n}=11$ ), respectively.

Crocker et al. (1999) studied the temporal pattern of ovipositional readiness of Phyllophaga hirtiventris (Horn, 1887), P. rubiginosa (LeConte, 1856), P. congrua (LeConte, 1856) and P. crassissima (Blanchard, 1850) and found, respectively, and average of $15.60,8.40,7.07$ and 4.40 eggs per female. They verified that, as the flight season go on, the number of eggs diminished in $P$. congrua, the opposite occurring with the other species.

Biology. Adults of L. fuscus kept in laboratory in plastic boxes provided the eggs necessary for biological studies. Average egg size was $1.5 \times 1.0 \mathrm{~mm}(\mathrm{n}=200)$. Freshly laid eggs 


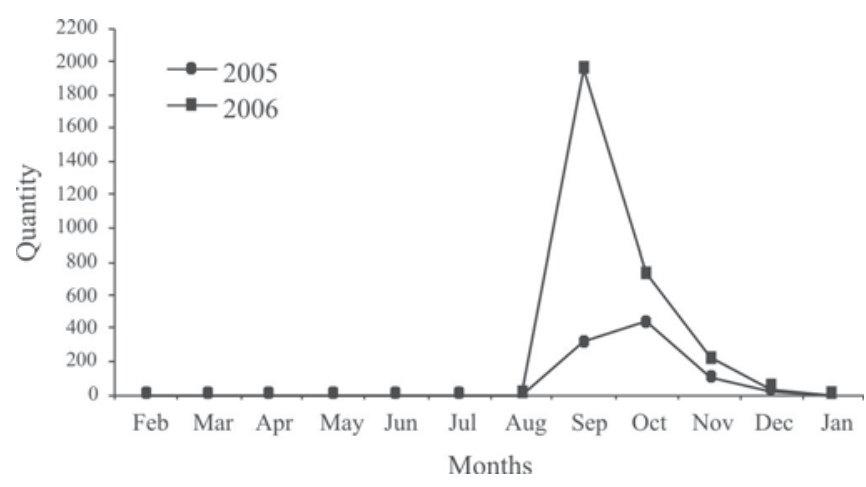

Fig. 1. Number of Liogenys fuscus Blanchard, 1830 (Coleoptera, Scarabaeidae, Melolonthinae) collected with light trap from February 2005 to January 2006, in Aquidauana, Mato Grosso do Sul, Brazil.

were white and became yellow near hatching. They were laid individually in soil chambers with mean dimensions of $2.0 \times 1.5$ $\mathrm{mm}(\mathrm{n}=80)$ or in groups of $3-10($ mean $8 ; n=25)$ in chambers averaging $4.0 \times 3.5 \mathrm{~mm}$.

Embryonic development of L. fuscus lasted an average of 14.30 days (Table 1). Oliveira et al. (1996) found 13.80 days for P. cuyabana and Silva \& Loeck (1996) recorded 12.00 days for D. abderus.

The first instar lasted averaged 28.50 days; the second, 48.80 days; and the third, 68.20 days (Table 1). Aragón-García et al. (2005) found the following mean duration for larval instars of Phyllophaga ravida (Blanchard, 1850): first 24.22 days, second 29.47 days and third 99.14 days. For P. cuyabana, Oliveira et al. (1996) reported the 26.90 days for the first instar, 34.40 for the second and 80.80 for the third. Reinhard (1940) studied the biology of P. lanceolata (Say, 1825) and found 51.00, 180.00 and 240.00 days for first, second and third instars respectively.

The average dimensions of cephalic head were $1.10 \mathrm{~mm}$, $2.30 \mathrm{~mm}$ and $3.30 \mathrm{~mm}$ for first, second and third instars, respectively; the growth rate was 1.64 as determined by the Dyar rule. Phyllophaga cuyabana presented a growth rate of 1.67 (Oliveira et al. 1996).

The mean duration of pre-pupal period of L. fuscus was 120.20 days (Table 1). Just before larval activity ceased, the white pre-pupa built a chamber with internal dimensions of $2.5 \times 1.1 \mathrm{~cm}$ in the bottom of plastic rearing containers. The pre-pupa stayed inside the chamber until pupation. According Oliveira et al. (1996) the active period of third instar of $P$. cuyabana lasted 80.8 days and the inactivity 132.9 days; the inactivity period refers to the time that the larva takes to metamorphose to pupa.

The pupal phase of L. fuscus lasted an average of 27.5 days. Aragón-García et al. (2005) studied the life cycle of $P$. ravida, $P$. macrocera (Bates, 1888), $P$. vetula (Horn, 1887), $P$. ilhuicaminai Morón, 1997 and P. obsoleta (Blanchard, 1950), and found that the average pupal period lasted 33.36, 29.15, 73.3, 34.12 and 54.1 days, respectively. King (1984) determined that the pupal period of $P$. menetriese Blanchard, 1853 lasts an average of 34.4 days.
After eclosion, the adults of L. fuscus stay in the pupal chamber an average of 20 days (range: $18-30 ; n=27$ ), after which they dig to the soil surface. Adult lifespan averages 23.6 days (range: $2-37 ; \mathrm{n}=55$ ). For $P$. cuyabana Oliveira et al. (1996) reported that the adults live and average of 32.9 days.

Pairs of some of 55 emerged adults of L. fuscus were reared in plastic boxes. Females laid an average of 4.5 eggs (range: 3 $-9 ; n=10)$. In seven females and 15 males malformations in elytra was observed.

Aragón-García et al. (2005) studied the life cycle of five species of Phyllophaga Harris, 1827, and found that females of $P$. ravida laid 18 to 32 eggs, $P$. macrocera about $21, P$. vetula about 25, P. ilhuicaminai ca. 16 and P. obsoleta 23 eggs in mean.

The mean time required by L. fuscus to complete the whole life cycle (from egg to adult) was 305.6 days, characterizing the species as univoltine. Aragón-García et al. (2005) studied the biologies of $P$. ravida, $P$. macrocera, $P$. vetula, $P$. ilhuicaminai and $P$. obsoleta, and found that these species complete their cycle, from egg to adult, in 200.19, 218.6, 272.19, 207.15 and 227.14 days respectively.

Flight time and sexual behavior. The use of light traps made possible observation of the flight activity of L. fuscus. The adults started to fly at 06:00 pm and stopped at 06:00 am. The largest number of adults was observed between 07:00 pm and 10:00 pm and no significant differences in the number of specimens were found among the flight times $(\mathrm{P}<0.05 \%)$. Adults of $P$. cuyabana emerge from soil at 07:15 pm and stop flying at 08:30 pm (Oliveira et al. 1996).

As soon as they began flight adults were collected and brought to laboratory for observation of sexual behavior. Females $(n=34)$ and males $(n=48)$ often scraped the hind legs together or on the abdomen. This scraping behavior is probably behavior coincident with pheromone release as copulation began immediately thereafter. Copulation lasted an average of 25 minutes (range: $10-30 \mathrm{~min}$; $\mathrm{n}=26$ ).

Oliveira \& Garcia (2003) observed the mating behavior of $P$. cuyabana, and noted that the females raise the third pair of

Table I. Duration (mean \pm EP) of phases of development of Liogenys fuscus Blanchard, 1830 (Coleoptera, Scarabaeidae, Melolonthinae) in laboratory $\left(26 \pm 1^{\circ} \mathrm{C}, 12\right.$ hours photophase).

\begin{tabular}{lcccc}
\hline Phase & $\begin{array}{c}\text { Duration } \\
\text { (days) }\end{array}$ & $\mathrm{N}$ & $\begin{array}{c}\text { Interval of } \\
\text { variation }\end{array}$ & $\begin{array}{c}\text { Viability } \\
(\%)\end{array}$ \\
\hline Egg & $14.3 \pm 0.26$ & 506 & $03-23$ & 79.1 \\
$1^{\text {st }}$ instar & $28.5 \pm 0.60$ & 400 & $21-40$ & 50.8 \\
$2^{\text {nd }}$ instar & $48.8 \pm 3.61$ & 203 & $14-124$ & 56.7 \\
$3^{\text {rd }}$ instar & $68.2 \pm 6.88$ & 115 & $26-197$ & 76.5 \\
Pre-pupa & $120.2 \pm 6.90$ & 88 & $34-164$ & 77.3 \\
Pupa & $27.5 \pm 2.55$ & 68 & $15-68$ & 80.9 \\
Adult & $23.6 \pm 1.77$ & 55 & $04-37$ & 60.0 \\
\hline Egg to adult & $305.6 \pm 4.37$ & 55 & $255-348$ & 10.9 \\
\hline
\end{tabular}

$\mathrm{N}=$ number of specimens. 
legs, expose the last abdominal segments and a yellow glandular region which probably releases a sexual pheromone. Some of them scraped the hind legs on the yellow gland; scraping ceased when copulation began, which lasted 83.9 minutes. Leal et al. (1992) observed that the females of Holotrichia parallela (Motschulsky, 1854) (Melolonthinae) exposed the abdominal gland and released the sexual pheromone.

Aragón-García et al. (2005) noted that females of $P$. vetula ready to mate expose the genital sac and just before copulation they dig while the males stays on soil surface. The mating lasts five to 10 minutes, and after this the females bury themselves in the soil.

Pre-copulation behavior was observed in fifteen pairs of L. fuscus. Males walk or fly around the females, which stay immobile for a continually pulsating abdomen. Subsequently, the male mounts the female and begins copulation. Arakaki et al. (2004) studied the copulation behavior of Dasylepida ishigakiensis (Niijima \& Kinoshita, 1927) (Scarabaeidae, Melolonthinae) and observed the same pulsating abdominal movements in female, which they regarded as calling behavior.

On eight occasions males and females were observed forming groups of about 20 individuals attempting to copulate without apparent success. Careful separation of these groups always revealed only a single pair in copulo. Copulating adults probably release a pheromone that stimulates aggregation. The same aggregation behavior was observed by Garcia et al. (2003) for P. cuyabana.

Aragón-García et al. (2005) observed that the males of $P$. vetula emerge and begin to fly before females. They soon converge on the ground where females are emerging and compete for them.

In the laboratory females $(n=12)$ were observed to mate twice, each time on a different day with a different male. Males $(\mathrm{n}=9)$ remain mounted on female for up to five minutes before copulation is initiated. Some males $(\mathrm{n}=11)$ remained with females for 40 minutes after copulation had ended. In the field most of mating activity occurred between 07:00 and 08:30 pm, but in the laboratory copulation was observed in the mornings and afternoons.

Acknowledgments. To Fundação de Apoio ao Desenvolvimento do Ensino, Ciência e Tecnologia do Estado de Mato Grosso do Sul (FUNDECT) by financial support and Dr. W. D. Edmonds (Marfa, Texas, USA) for comments and suggestions.

\section{REFERENCES}

Aragón-García, A.; M. A. Morón; J. F. López-Olguín \& L. M. CervantesPeredo. 2005. Ciclo de vida y conducta de cinco espécies de Phyllophaga Harris, 1827 (Coleoptera: Melolonthidae: Melolonthinae). Acta Zoológica Mexicana 21: 87-89.

Arakaki, N.; Y. Sandoyama; M. Kishita; A. Nagayama, A. Oyafuso; M. Ishimine; M. Ota; T. Akino; M. Fukaya; Y. Hirai; K. Yamamura \& S. Wakamura. 2004. Mating behavior of the scarab beetle Dasylepida ishigakiensis (Coleoptera: Scarabaeidae). Japanese Journal of Applied Entomology and Zoology 39: 669-674.

Ávila, C. J. \& A. E. Pípolo. 1992. Ocorrência e danos do "coró" (Coleoptera: Scarabaeidae - Melolonthinae) em trigo na região de Dourados, MS. Anais da Sociedade Entomológica do Brasil 21: 261 .

Crocker, R. L.; W. T. Nailon, Junior; J. H. Matis \& R. E. Woodruff. 1999. Temporal Pattern of Ovipositional Readiness in Spring Species of Phyllophaga (Coleoptera: Scarabaeidae) en North Central Texas. Annals of the Entomological Society of America 92: 47-52.

Garcia, M. A.; L. J. Oliveira \& M. C. N. Oliveira. 2003. Aggregation behavior of Phyllophaga cuyabana (Moser) (Coleoptera: Melolonthidae): Relationships between sites chosen for mating and offspring distribution. Neotropical Entomology 32: 537-542.

King, A. B. S. 1984. Biology and identification of white grubs (Phyllophaga) of economic importance in Central America. Tropical Pest Management 30: 36-50.

Leal, W. S.; S. Matsuyama; Y. Kuwahara; S. Wakamura \& M. Hasegawa. 1992. An amino acid derivative as the sex pheromone of scarab beetle. Naturwissenschaften 79: 184-185.

Novelo, E. R. \& M. A. Morón. 2005. Fauna de Coleoptera Melolonthidae y Passalidae de Tzucacab y Conkal, Yucatán, México. Acta Zoológica Mexicana 21: 15-49.

Ochieng, S. A.; P. S. Robbins; W. L. Roelofs \& T. C. Baker. 2002. Sex pheromone reception in the scarab beetle Phyllophaga anxia (Coleoptera: Scarabaeidae). Annals of the Entomological Society of America 95: 97-102.

Oliveira, L. J.; B. Santos; J. R. P. Parra; M. L. B. Amaral \& D. C. Magril. 1996. Ciclo biológico de Phyllophaga cuyabana (Moser) (Scarabaeidae: Melolonthinae). Anais da Sociedade Entomológica do Brasil 25: 431-437.

Oliveira, L. J. \& M. A. Garcia. 2003. Flight, feeding and reproductive behavior of Phyllophaga cuyabana (Moser) (Coleoptera: Melolonthidae) adults. Pesquisa Agropecuária Brasileira 38: 179-186.

Oliveira, L. J.; C. B. Hoffmann"Campo \& M. A. Garcia. 2000. Effect of soil management on the white grub population and damage in soybean. Pesquisa Agropecuária Brasileira 35: 887-894.

Pardo"Locarno, L. C.; J. Montoya; A. Schoonhoven \& A. C. Belloti. 2005. Structure and composition of the white grub complex (Coleoptera: Scarabaeidae) in agroecological systems of northern Cauca, Colombia. Florida Entomologist 88: 355-363.

Reinhard, H. J. 1940. The life history of Phyllophaga lanceolata (Say) and Phyllophaga crinita Burmeister. Journal of Economic Entomology 33: 572-578.

Silva, M. T. B. \& A. E. Loeck. 1996. Ciclo evolutivo e comportamento de Diloboderus abderus Sturm (Coleoptera: Melolonthidae) em condições de plantio direto. Anais da Sociedade Entomológica do Brasil 25: 329-337.

Silva, M. T. \& E. C. Costa. 2002. Nível de controle de Diloboderus abderus em aveia preta, linho, milho e girassol. Ciência Rural 32: $7-12$.

Silva, M. T. B. \& A. Boss. 2002. Controle de larvas de Diloboderus abderus com inseticidas em trigo. Ciência Rural 32: 191-195.

Received 27/11/2007; accepted 14/07/2008 